3. The ultraviolet absorption spectra of the flavone glucosiduronic acids and of their aglycones have been compared.

The author wishes to thank Dr G. A. Levvy for his interest in this work, and Dr J. G. Dony and Mr I. W. Evans for their willing co-operation in obtaining plant material. $\mathrm{He}$ is indebted to the Royal Botanic Gardens, Kew, for presenting seeds of $S$. tournefortii.

\section{REFERENCES}

Bargellini, G. (1915). Gazz. chim. ital. 45 I, 69.

Bargellini, G. (1919). Gazz. chim. ital. 49 II, 47.

Charaux, C. \& Rabaté, J. (1940a). J. Pharm. Chim., Paris, 8, 155.

Charaux, C. \& Rabaté, J. (1940b). J. Pharm. Chim., Paris, 9, 401.
Hattori, S. (1932). Acta phytochim., Tokyo, 6, 131.

Levvy, G. A. (1946). Biochem. J. 40, 396.

Levvy, G. A. (1948). Biochem. J. 42, 2.

Levvy, G. A. (1954). Biochem. J. 58, 462.

Levvy, G. A. \& Marsh, C. A. (1952). Biochem. J. 52, 690.

Lohmar, R., Dimler, R. J., Moore, S. \& Link, K. P. (1942). J. biol. Chem. 143, 551.

Marsh, C. A. \& Levvy, G. A. (1953). Biochem. J. 53, xxxix.

Miwa, T. (1932). Acta phytochim., Tokio, 6, 154.

Mölisch, H. \& Goldschmiedt, G. (1901). Mh. Chem. 22, 679.

Plant, S. G. P. (1931). Rep. Progr. Chem. 28, 147.

Sastri, V. D. N. \& Seshadri, T. R. (1946). Proc. Indian Acad. Sci. 23 A, 262.

Shibata, K. \& Hattori, S. (1930). Acta phytochim., Tokyo, 5, 117.

Shibata, K., Iwata, S. \& Nakamura, M. (1923). Acta phytochim., Tokyo, 1, 105.

\title{
The Amino Acid Composition of Wool
}

\author{
By M. C. CORFIELD ANd A. ROBSON \\ Wool Industries Research Association, Torridon, Headingley, Leeds 6
}

(Received 5 July 1954)

When the present work was started early in 1953 no complete amino acid analysis of a single wool sample had been published, although Graham, Waitkoff \& Hier (1949) had estimated fourteen amino acid constituents of a wool hydrolysate, chiefly by microbiological methods. While this paper was in preparation, however, our attention was drawn to a paper by Simmonds (1954), who has completed the amino acid analysis of an Australian 64's quality wool. The wool sample whose analysis is reported here was of the same quality, and it is of interest, therefore, to compare the two analyses. For a survey of amino acid analyses of wool, previously published in the literature, reference should be made to Simmonds (1954).

\section{EXPERIMENTAL}

\section{Chromatographic separations and estimations of amino acids}

All the columns used for starch chromatography were of $0.9 \mathrm{~cm}$. diameter and $30 \mathrm{~cm}$. length and were prepared according to the directions of Stein \& Moore (1948) from starch manufactured by Gordon Slater Ltd., Manchester. Six different types of chromatograms were employed in the analysis of wool hydrolysates. Leucine, isoleucine, phenylalanine and methionine were separated on starch columns eluted with benzyl alcohol- $n$-butanol-water $(1: 1: 0 \cdot 280$, by vol.). The volume of water in the mixture was smaller than that used by Stein \& Moore (1948) because the columns were run at $18^{\circ}$. The columns were loaded with $3.5 \mathrm{mg}$. of hydrolysate and $0.5 \mathrm{ml}$. fractions were collected for the estimations of leucine, phenylalanine and isoleucine, but for the accurate estimation of methionine, which occurs to the extent of $0.5 \%$ in the hydrolysate, $10 \mathrm{mg}$. loads were applied and $1.5 \mathrm{ml}$. fractions collected. Thiodiglycol was added to the eluting solvent for the methionine estimations. This chromatogram is illustrated in Fig. 1 and referred to hereafter as starch I. Valine and tyrosine were separated from $2.5 \mathrm{mg}$. of wool hydrolysate on starch columns eluted with $17 \%(v / v)$ aqueous $0.57 \mathrm{~N}-\mathrm{HCl}$ in $n$-butanol; $0.5 \mathrm{ml}$. fractions were collected (Stein \& Moore, 1948). The valine peak coincided with that of methionine, and the methionine contribution to the combined peak was deducted to give the

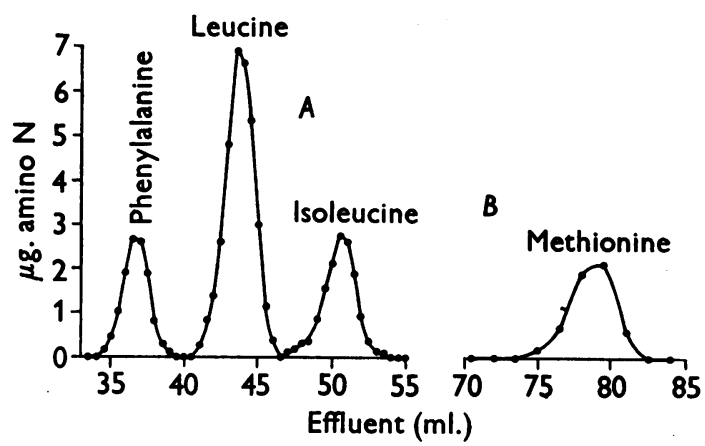

Fig. 1. Elution of amino acids from chromatogram starch $I$ (Nin.) (see text). $A, 3.5 \mathrm{mg}$. of wool hydrolysate for estimations of phenylalanine, leucine and isoleucine $(0.5 \mathrm{ml}$. fractions); $B, 10 \mathrm{mg}$. of wool hydrolysate for estimation of methionine only (1.5 ml. fractions). 
valine content. The chromatogram is shown in Fig. 2 and referred to below as starch II. Tyrosine was also separated from $2 \mathrm{mg}$. of hydrolysate on a starch column eluted with $0.1 \mathrm{~N}-\mathrm{HCl}$, and $0.5 \mathrm{ml}$. fractions were collected (Moore \& Stein, 1949). This chromatogram is referred to as starch III. Columns loaded with $3 \mathrm{mg}$. of wool hydrolysate and eluted with $n$-propanol- $0.5 \mathrm{~N}-\mathrm{HCl}(2: 1$, by vol.) were used for the separation of serine, glycine, arginine, lysine, histidine and cystine, $1 \mathrm{ml}$. fractions being collected (Moore \& Stein, 1949). The arginine peak coincided with that of $\mathrm{NH}_{3}$, but the latter was not estimated when the ${ }^{64} \mathrm{Cu}$ radiometric method of Blackburn \& Robson (1953) was used to determine arginine. Although histidine was separated, it could not be accurately estimated in $3 \mathrm{mg}$. of hydrolysate. The chromatogram is shown in Fig. 3 and referred to later as starch IV. The amino acids separated on starch IV were also separated from $3 \mathrm{mg}$. of hydrolysate on a starch column eluted with $n$-butanol- $n$-propanol-0.1 N-HCl (1:2:1, by vol.) until $82 \mathrm{ml}$. had been collected, when the solvent was changed to $n$-propanol-0.5 N-HCl (2:1, by vol.) (Moore \& Stein, 1949). $1 \mathrm{ml}$. fractions were collected. This chromatogram separates

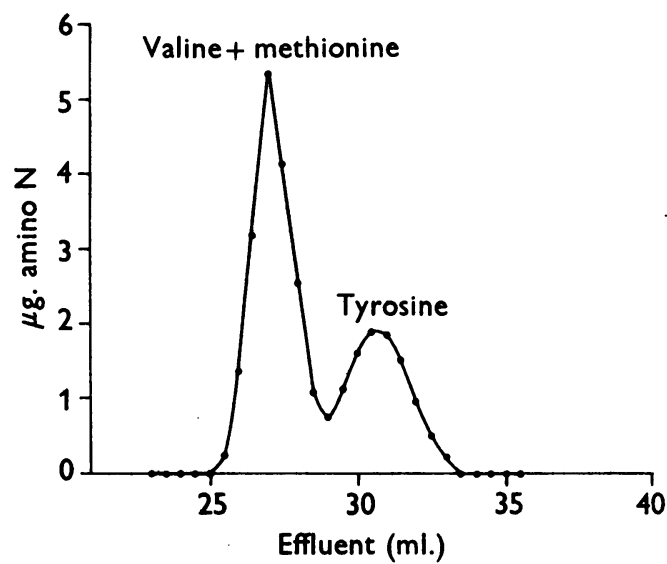

Fig. 2. Elution of valine, methionine and tyrosine from chromatogram starch II (Nin.) (see text). $2.5 \mathrm{mg}$. of wool hydrolysate; $0.5 \mathrm{ml}$. fractions.

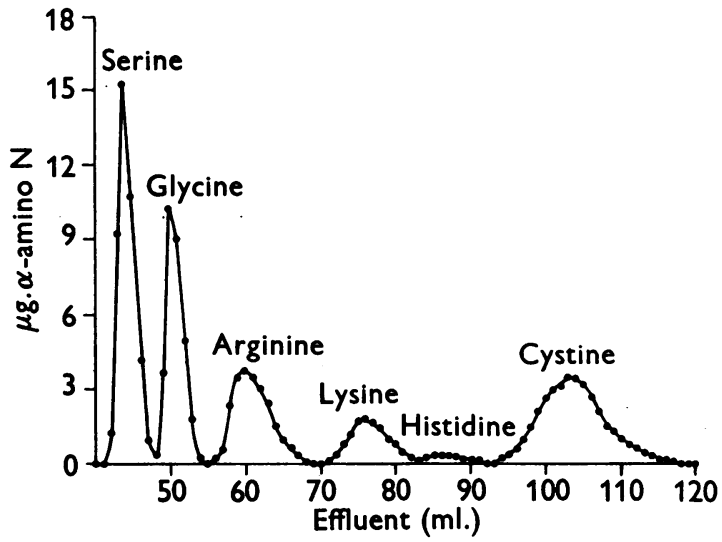

Fig. 3. Elution of serine, glycine, arginine, lysine, histidine and cystine from chromatogram starch IV $\left({ }^{64} \mathrm{Cu}\right.$ ) (see text). $3 \mathrm{mg}$. of wool hydrolysate; $1 \mathrm{ml}$. fractions. arginine and $\mathrm{NH}_{3}$, and is referred to as starch $\mathrm{V}$. On chromatograms starch IV and starch $V$ the alanine and glutamic acid peaks coincide, and threonine and aspartic acid are only partially separated. Experiments with various buffered solvent mixtures showed that good separations of proline, $\mathrm{NH}_{3}$, threonine, alanine and glutamic acid could be achieved by eluting starch columns with $n$-butanol$n$-propanol-citrate buffer (1:2:1, by vol.). The buffer (pH 3) was a mixture of $0.1 \mathrm{~m}$ disodium hydrogen citrate and $0 \cdot 1 \mathrm{~N}-\mathrm{HCl}(2: 3$, by vol.). $3 \mathrm{mg}$. of wool hydrolysate were applied and $1 \mathrm{ml}$. fractions collected. This chromatogram is shown in Fig. 4 and referred to as starch VI. No satisfactory means of completely separating aspartic acid from the other amino acids in wool hydrolysates on starch was found, and the aspartic acid contents were obtained by subtracting the estimated amount of threonine from the combined aspartic acid and threonine peaks obtained on starch IV and starch V.

Histidine, owing to its sparsity in wool hydrolysates, cannot be accurately determined by starch chromatography, as amounts of wool hydrolysate in excess of $3 \mathrm{mg}$. prevent its complete isolation from lysine and cystine. However, Dowex50 columns $0.9 \mathrm{~cm}$. in diameter and $15 \mathrm{~cm}$. in length, prepared and eluted according to Moore \& Stein (1951), enabled $19 \mathrm{mg}$. of wool hydrolysate to be fractionated with excellent resolution of the histidine and lysine peaks. This chromatogram is illustrated in Fig. 5 and referred to as Dowex-50.

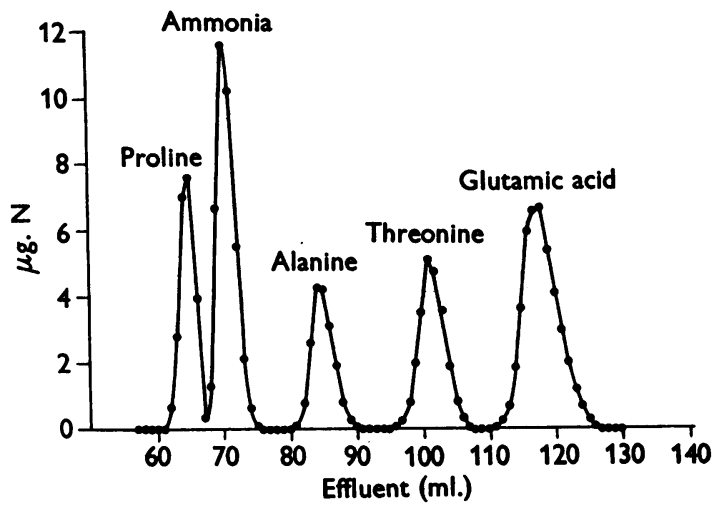

Fig. 4. Elution of proline, ammonia, alanine, threonine and glutamic acid from chromatogram starch VI (Nin.) (see text). $3 \mathrm{mg}$. of wool hydrolysate; $1 \mathrm{ml}$. fractions.

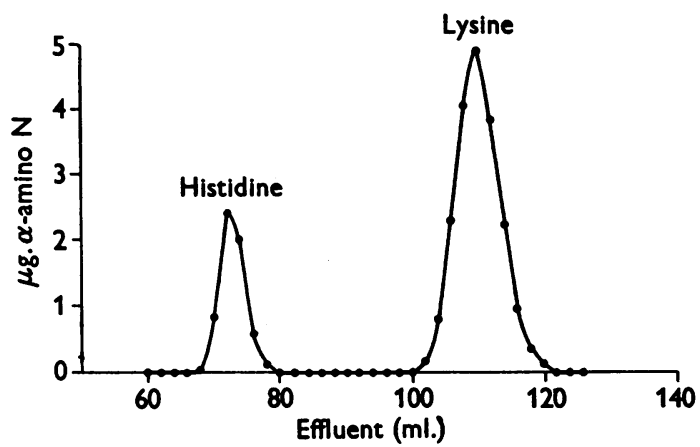

Fig. 5. Elution of histidine and lysine from chromatogram Dowex-50 (Nin.) (see text). $19 \mathrm{mg}$. of wool hydrolysate; $2 \mathrm{ml}$. fractions. 
The recoveries of the amino acids from the seven different types of chromatogram, on separation from amino acid mixtures made to simulate a wool hydrolysate, were the same as those recorded by Moore \& Stein, viz. $100 \pm 3 \%$ for all except glutamic acid and aspartic acid, which were recovered in 93 and $94 \%$ yields, respectively. The recovery of aspartic acid was confirmed by starch chromatography with ${ }^{14} \mathrm{C}$-labelled L-aspartic acid, when $94 \%$ of the total activity was recovered. The only exception to the above was the $100 \pm 3 \%$ recovery of glutamic acid from starch VI, as there was no partial esterification of the acid in the buffered solvent.

Amino acid estimations were carried out in part by the photometric ninhydrin method of Moore \& Stein (1948) and in part by the ${ }^{64} \mathrm{Cu}$ radiometric method of Blackburn \& Robson (1953), as modified for use with starch chromatography by Corfield \& Robson (1953). The latter method could not be used to estimate amino acids separated on starch I, as the solvent system prevented complete reaction between $\mathrm{Cu}^{2+}$ ions and amino acids and depressed the $\mathrm{Cu}^{2+}$ concentration over the copper phosphate suspension from $4 \times 10^{-5} \mathrm{M}$ to $2 \times 10^{-6} \mathrm{M}$. Nor could it be used with fractions containing citrate, which forms complexes with $\mathrm{Cu}^{2+}$ ions. In all cases standard amino acid calibration curves were used, the data being obtained under reaction conditions identical with those for the column fractions. Calibration curves were repeated for each batch of ${ }^{\circ 4} \mathrm{Cu}$ because of changes in its specific activity, and also with different batches of ninhydrin reagent, which gave small variations in colour yields. All the amino acids used as standards were tested by filter-paper chromatography and elementary analysis, and shown to be free from amino acid impurities and from $\mathrm{NH}_{3}$, sulphate and halide ions. The histidine and lysine standards were prepared from L-histidine monohydrochloride and L-lysine dihydrochloride respectively. In the presentation of the results, the chromatogram type has been stated with the abbreviated method of estimation in brackets, thus: starch IV $\left({ }^{64} \mathrm{Cu}\right)$; Dowex-50 (Nin.).

\section{Other amino acid estimations}

Tyrosine was estimated by the methods of Thomas (1944) and of Lugg (1937). Arginine was estimated by the method of Vickery (1940), glycine by the method of Alexander, Landwehr \& Seligman (1945) and cystine by the method of Shinohara (1935). Serine and threonine were estimated by the method of Rees (1946).

\section{Estimation of tryptophan}

Tryptophan has proved to be the most difficult of all the amino acids in wool to estimate, as it is wholly or partially destroyed during hydrolysis. The methods of Lugg (1937), Brand \& Kassell (1939), Sullivan \& Hess (1944) and Spies \& Chambers $(1948,1949)$ have been used in these laboratories, but the tryptophan determinations were extremely erratic.

No tryptophan is present in acid hydrolysates of wool, and the amounts present in alkaline hydrolysates vary with hydrolytic conditions. The only satisfactory method for tryptophan estimation was found to be that of Moore \& Stein (1949) on chromatograms of the type starch III, where the tryptophan peak appears after tyrosine. $1 \mathrm{~g}$. (dry wt.) samples of wool were sealed in Pyrex glass bulbs with 6.5 g. of recrystallized $\mathrm{Sr}(\mathrm{OH})_{2}, 8 \mathrm{H}_{2} \mathrm{O}$ and $10.8 \mathrm{ml}$. of water, and heated in an oven at $100^{\circ}$ for periods varying from 2 to $52 \mathrm{hr}$.
Strontium was precipitated as $\mathrm{SrSO}_{4}$ and removed by filtration, together with small amounts of $\mathrm{SiO}_{2}$, and the filtrates were concentrated to $10 \mathrm{ml}$. Samples $(0.19 \mathrm{ml}$.) of the hydrolysates were fractionated on starch III chromatograms. There was no interference with the tryptophan peak by slow-moving peptides in the partial hydrolysates, but when the $2 \mathrm{hr}$. hydrolysate was examined, a small peak, probably due to a peptide, appeared in front of the tryptophan. The relationship between the tryptophan found and the time of hydrolysis is shown in Fig. 6. The amount of tryptophan in wool was found by extrapolating the latter part of the curve back to zero time as shown.

\section{Decomposition of the amino acids of wool during acid hydrolysis}

Samples (approx. $0 \cdot 2$ g.) of glycine, DL-alanine, DL-valine, DL-leucine, DL-isoleucine, DL-phenylalanine, DL-serine, DLproline, L-arginine, L-cystine, DL-threonine, L-tyrosine, Lhistidine hydrochloride, L-lysine dihydrochloride, DLglutamic acid, DL-aspartic acid and DL-methionine were refluxed separately for $24 \mathrm{hr}$. with $25 \mathrm{ml}$. of $5 \mathrm{~N}-\mathrm{HCl}$. The $\mathrm{HCl}$ was removed by vacuum distillation and the residues were dissolved in $50 \mathrm{ml}$. of water. The $\mathrm{NH}_{3}$ contents of suitable samples of these solutions were determined with the apparatus of Markham (1942), using a suspension of $\mathrm{Mg}(\mathrm{OH})_{2}$ to liberate $\mathrm{NH}_{3}$. Other samples were made alkaline and aerated to remove any $\mathrm{NH}_{3}$, brought to $\mathrm{pH} 5$ with $\mathrm{HCl}$, and their amino acid contents estimated by the photometric ninhydrin method (Moore \& Stein, 1948).

\section{Total $N$ and ammonia}

The total $\mathrm{N}$ contents of conditioned wool samples were determined (Chibnall, Rees \& Williams, 1943). Digestion was for $16 \mathrm{hr}$. and twelve determinations were made. For the determination of amide $\mathrm{N}$ about $1 \mathrm{~g}$. of conditioned wool was refluxed with $50 \mathrm{ml}$. of $2 \mathrm{~N}-\mathrm{HCl}$ until the wool dissolved completely (usually $5 \mathrm{hr}$.). The solution was partly neutralized with $5 \mathrm{~g}$. of $\mathrm{KOH}$ and diluted to $500 \mathrm{ml}$. $5 \mathrm{ml}$. of this solution were taken for estimation of $\mathrm{NH}_{3}$ in the Markham apparatus as above. The $\mathrm{NH}_{3}$ contents of $10 \mathrm{ml}$. samples of wool hydrolysates were likewise determined.

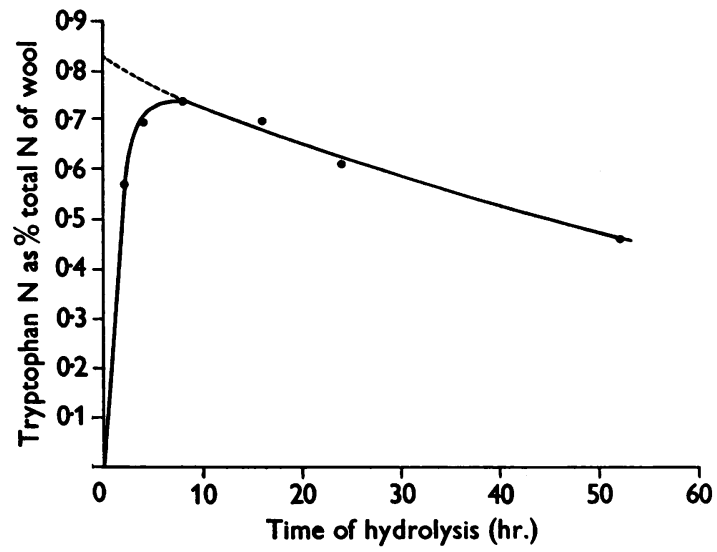

Fig. 6. Curve showing the amounts of tryptophan found after alkaline hydrolysis of wool for varying periods of time (see text). 


\section{Total $S$, ash and moisture}

The total S of a conditioned wool sample was determined by the Benedict-Denis method (Barritt, 1934a). A weighed sample of conditioned wool was ashed to constant weight in a Pt crucible at $800^{\circ}$. To determine dry matter, a weighed sample of conditioned wool was heated to constant weight in an oven at $102^{\circ}$.

\section{Wool sample and hydrolysis procedure}

A quantity (6 lb.) of Australian Merino 64's quality virgin wool was 'tipped' by cutting off the top third of each lock of fibres to remove wool degraded by weathering. The root wool was extracted 6 times with the azeotropic mixture of benzene and methanol at 58.4. After drying in air, each lock was washed separately in water at $45^{\circ}$, the bulk of the water removed in a centrifugal drier, and the wool air-dried for two days. Adhering vegetable matter was removed by combing the locks through a clean steel comb. The locks were drawn out by hand into slivers, gilled into one long sliver and chopped into pieces $1 / 32$ in. in length on a special guillotine. After removing the last traces of grease by Soxhlet extraction with benzene-methanol, the wool was thoroughly stirred with distilled water (liquor to wool ratio, $10: 1$ ), and the water decanted.

The washing procedure was repeated 5 times and the wool finally separated on a large sintered glass filter. After drying in an oven at $40^{\circ}$ to a water regain of about $8 \%$, the sample was stored in stoppered bottles in the dark until required. Before use, a bottle was unstoppered and the wool conditioned for 1 week in a humidity room controlled at $15 \cdot 5^{\circ}$ and $65 \%$ relative humidity. Every time a sample was taken for analysis, a similar sample was removed for moisture-content determination.

With the exception of the hydrolysates prepared for tryptophan determinations, all hydrolysates were prepared by refluxing $1 \mathrm{~g}$. (dry wt.) of wool for $24 \mathrm{hr}$. with $20 \mathrm{ml}$. of $5 \mathrm{~N}-\mathrm{HCl}$, removing $\mathrm{HCl}$ in vacuo and making the residue up to $10 \mathrm{ml}$. with water.

\section{RESULTS}

The results of all the amino acid analyses are recorded in Table 1. Where amino acids were estimated by both the radiometric method and the ninhydrin method, the results show good agreement. The colour yields obtained for all the amino acids by the ninhydrin method were in accord with those of Moore \& Stein $(1948,1949,1951)$ except in the solvent mixture $n$-butanol-benzyl alcoholwater $(1: 1: 0 \cdot 280$, by vol.) in which the colour yields of phenylalanine, leucine and isoleucine were low by 9,9 and $6 \%$ respectively. Three different samples of DL-leucine, three of DL-isoleucine and two of DL-phenylalanine, and recrystallized specimens of these amino acids, were examined, but no variation in colour yield greater than $0.5 \%$ was observed. Purification of the solvents used made no difference to the colour yields.

The results of experiments carried out to determine the amounts of decomposition of the amino acids of wool during hydrolysis are shown in
Table 2. Only serine, threonine, phenylalanine and arginine decomposed, and the arginine decomposition was insignificant. Threonine showed $8 \cdot 3 \%$ decomposition when refluxed for $24 \mathrm{hr}$. with $5 \mathrm{~N}-\mathrm{HCl}$, but only $3.5 \%$ loss could be accounted for as ammonia, on the basis of one mole of ammonia formed for one mole of threonine decomposed. This is contrary to the findings of Rees (1946), but agrees with recent work by Phillips (1954), who found that threonine decomposed to the extent of 7-9\% with the liberation of $3 \%$ of its nitrogen as ammonia, under hydrolytic conditions slightly different from those we employed.

The ash content of the wool sample was $0.18 \%$, its total nitrogen content $16.35 \%$, its amide nitrogen content $1 \cdot 10 \%$ and the average ammonianitrogen content of its acid hydrolysates $1.40 \%$.

\section{DISCUSSION}

The estimations of serine and threonine by the method of Rees (1946), of tyrosine by the methods of Lugg (1937) and Thomas (1944), and of arginine by the method of Vickery (1940) were in good agreement with the chromatographic estimations, but glycine estimated according to Alexander et al. (1945) gave a value $15 \%$ lower than the chromatographic figure. In this case the latter is considered to be nearer the true value, since complete separation of glycine from the hydrolysate removes possible sources of interference with its estimation. The chromatographic estimation of cystine was $20 \%$ lower than the amount found by the method of Shinohara (1935), and if the latter estimate is correct the $3.38 \%$ sulphur content of the wool sample can be wholly accounted for as methionine sulphur and cystine sulphur. This is in accord with similar analyses made in these laboratories and elsewhere (Rimington, 1929; Barritt, 1934b; Bailey, 1937; Cuthbertson \& Phillips, 1945). On the other hand, Stein \& Moore (1949) found that the cystine contents of hydrolysates of $\beta$-lactoglobulin and bovine serum albumin were $10 \%$ lower than cystine determined by other methods, and the figure for cystine in wool hydrolysates found by Simmonds (1954) using ion-exchange resin chromatography (Moore \& Stein, 1951) was $38 \%$ lower than the amount he found by Shinohara's method. Stein \& Moore (1949) stated that their cystine results may be low because of the differences in times of hydrolysis of the two samples. However, in our experience with wool hydrolysates, the Shinohara method gives the same cystine value for times of hydrolysis from 4 to $24 \mathrm{hr}$. Another method for cystine estimation as, for example, an isotopedilution method, would furnish independent analyses and help to resolve the problem. Such a method is being investigated in our laboratories at 
Table 1. Amino acid analyses of wool hydrolysates

\begin{tabular}{|c|c|c|c|c|c|c|}
\hline$\underset{\text { acid }}{\text { Amino }}$ & Hydrolysate & $\begin{array}{l}\text { Method of separation } \\
\text { and estimation }\end{array}$ & $\begin{array}{c}\text { No. of } \\
\text { estimations }\end{array}$ & $\begin{array}{l}\text { Amino acid } N \\
(\text { as } \% \text { total } N)\end{array}$ & $\begin{array}{l}\text { acid } \mathrm{N} \\
\text { (as } \% \\
\text { total } \stackrel{\mathrm{N}}{\mathrm{N}})\end{array}$ & $\begin{array}{l}\text { Amino } \\
\text { acid/100 g. } \\
\text { wool }\end{array}$ \\
\hline Alanine & $\begin{array}{l}\mathbf{A} \\
\mathbf{B}\end{array}$ & $\begin{array}{l}\text { Starch VI (Nin.) } \\
\text { Starch VI (Nin.) }\end{array}$ & $\begin{array}{l}\mathbf{3} \\
\mathbf{3}\end{array}$ & $\left.\begin{array}{l}4 \cdot 05 \pm 0 \cdot 04 \\
4 \cdot 20 \pm 0 \cdot 04\end{array}\right\}$ & $4 \cdot 12$ & $4 \cdot 3$ \\
\hline Arginine & $\begin{array}{l}\mathbf{A} \\
\mathbf{B} \\
\mathbf{C} \\
\mathbf{D} \\
\mathbf{F} \\
\mathbf{G}\end{array}$ & $\begin{array}{l}\text { Starch V (Nin.) } \\
\text { Starch V (Nin.) } \\
\left.\text { Starch IV ( }{ }^{(64} \mathrm{Cu}\right) \\
\text { Starch IV }{ }^{\left({ }^{64} \mathrm{Cu}\right)} \\
\text { Vickery (1940) } \\
\text { Vickery (1940) }\end{array}$ & $\begin{array}{l}2 \\
2 \\
1 \\
1 \\
2 \\
2\end{array}$ & $\left.\begin{array}{l}19 \cdot 4 \pm 0 \cdot 4 \\
18 \cdot 8 \pm 0 \cdot 2 \\
19 \cdot 2 \\
19 \cdot 6 \\
21 \cdot 2 \pm 0 \cdot 2 \\
20 \cdot 1 \pm 0 \cdot 1\end{array}\right\}$ & $\begin{array}{l}19 \cdot 1 \\
20 \cdot 6\end{array}$ & $10 \cdot 4$ \\
\hline Aspartic acid & $\begin{array}{l}\mathbf{A} \\
\mathbf{A} \\
\mathbf{B} \\
\mathbf{B}\end{array}$ & $\begin{array}{l}\text { Starch V (Nin.) } \\
\left.\text { Starch V }{ }^{64} \mathrm{Cu}\right) \\
\text { Starch V (Nin.) } \\
\left.\text { Starch V ( }{ }^{64} \mathrm{Cu}\right)\end{array}$ & $\begin{array}{l}2 \\
1 \\
2 \\
1\end{array}$ & $\left.\begin{array}{l}4 \cdot 15 \pm 0 \cdot 07 \\
4 \cdot 51 \\
4 \cdot 54 \pm 0 \cdot 19 \\
4 \cdot 35\end{array}\right\}$ & $4 \cdot 38$ & $6 \cdot 8$ \\
\hline Cystine & $\begin{array}{c}\mathbf{C} \\
\mathbf{E} \\
\mathbf{D} \\
\mathbf{E} \\
\mathbf{A} \\
\mathbf{A} \\
\mathbf{A}, \mathbf{B}, \mathbf{H}, \mathbf{I}, \mathbf{J}, \mathbf{K}\end{array}$ & $\begin{array}{l}\text { Starch IV }\left({ }^{64} \mathrm{Cu}\right) \\
\left.\text { Starch IV }{ }^{64} \mathrm{Cu}\right) \\
\text { Starch IV }\left({ }^{64} \mathrm{Cu}\right) \\
\text { Starch IV (Nin.) } \\
\text { Starch IV (Nin.) } \\
\text { Starch V (Nin.) } \\
\text { Shinohara (1935) }\end{array}$ & $\begin{array}{l}1 \\
1 \\
1 \\
1 \\
1 \\
2 \\
1 \\
6\end{array}$ & $\left.\begin{array}{l}\mathbf{7 \cdot 2 6} \\
\mathbf{6} \cdot 73 \\
7 \cdot 50 \\
7 \cdot 67 \\
7 \cdot 52 \pm 0 \cdot 02 \\
6 \cdot 83 \\
8 \cdot 73 \pm 0 \cdot 04\end{array}\right\}$ & $\begin{array}{r}7 \cdot 30 \\
8 \cdot 73\end{array}$ & $\begin{array}{l}10 \cdot 3 \\
12 \cdot 3\end{array}$ \\
\hline Glutamic acid & $\begin{array}{l}\mathbf{A} \\
\mathbf{B}\end{array}$ & $\begin{array}{l}\text { Starch VI (Nin.) } \\
\text { Starch VI (Nin.) }\end{array}$ & $\begin{array}{l}\mathbf{3} \\
\mathbf{3}\end{array}$ & $\left.\begin{array}{l}8 \cdot 53 \pm 0 \cdot 17 \\
8 \cdot 44 \pm 0 \cdot 16\end{array}\right\}$ & $8 \cdot 48$ & $14 \cdot 5$ \\
\hline Glycine & $\begin{array}{l}\text { C } \\
\mathbf{D} \\
\mathbf{A} \\
\mathbf{B} \\
\mathbf{A} \\
\mathbf{B} \\
\mathbf{D} \\
\mathbf{E} \\
\mathbf{C}\end{array}$ & $\begin{array}{l}\text { Starch IV }\left({ }^{64} \mathrm{Cu}\right) \\
\text { Starch IV }\left({ }^{64} \mathrm{Cu}\right) \\
\text { Starch IV (Nin.) } \\
\text { Starch IV (Nin.) } \\
\text { Starch V (Nin.) } \\
\text { Starch V (Nin.) } \\
\text { Alexander et al. (1945) } \\
\text { Alexander et al. (1945) } \\
\text { Alexander et al. (1945) }\end{array}$ & $\begin{array}{l}1 \\
1 \\
2 \\
1 \\
2 \\
2 \\
6 \\
5 \\
\mathbf{6}\end{array}$ & 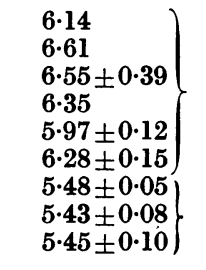 & $5 \cdot 45$ & $4 \cdot 8$ \\
\hline Histidine & $\begin{array}{l}\mathbf{A} \\
\mathbf{B}\end{array}$ & $\begin{array}{l}\text { Dowex-50 (Nin.) } \\
\text { Dowex-50 (Nin.) }\end{array}$ & $\begin{array}{l}\mathbf{1} \\
\mathbf{3}\end{array}$ & $\left.\begin{array}{l}1.87 \\
1.93 \pm 0.01\end{array}\right\}$ & 1.91 & $1 \cdot 2$ \\
\hline Isoleucine & $\begin{array}{l}\mathbf{E} \\
\mathbf{D} \\
\mathbf{C}\end{array}$ & $\begin{array}{l}\text { Starch I (Nin.) } \\
\text { Starch I (Nin.) } \\
\text { Starch I (Nin.) }\end{array}$ & $\begin{array}{l}\mathbf{1} \\
\mathbf{3} \\
\mathbf{2}\end{array}$ & $\left.\begin{array}{l}2 \cdot 50 \\
2 \cdot 40 \pm 0.06 \\
2 \cdot 48 \pm 0.06\end{array}\right\}$ & $2 \cdot 44$ & $\mathbf{3 \cdot 7}$ \\
\hline Leucine & $\begin{array}{l}\mathbf{E} \\
\mathbf{D} \\
\mathbf{C}\end{array}$ & $\begin{array}{l}\text { Starch I (Nin.) } \\
\text { Starch I (Nin.) } \\
\text { Starch I (Nin.) }\end{array}$ & $\begin{array}{l}\mathbf{1} \\
\mathbf{3} \\
\mathbf{2}\end{array}$ & $\left.\begin{array}{l}5 \cdot 90 \\
5 \cdot 86 \pm 0 \cdot 06 \\
5 \cdot 80 \pm 0 \cdot 16\end{array}\right\}$ & $5 \cdot 85$ & $8 \cdot 9$ \\
\hline Lysine & $\begin{array}{l}\mathbf{B} \\
\mathbf{C} \\
\mathbf{D} \\
\mathbf{E} \\
\mathbf{E} \\
\mathbf{A} \\
\mathbf{B} \\
\mathbf{A} \\
\mathbf{A} \\
\mathbf{B}\end{array}$ & $\begin{array}{l}\text { Starch V (Nin.) } \\
\text { Starch IV }{ }^{\left({ }^{44} \mathrm{Cu}\right)} \\
\text { Starch IV }{ }^{\left({ }^{4} \mathrm{Cu}\right)} \\
\left.\text { Starch IV ( }{ }^{84} \mathrm{Cu}\right) \\
\text { Starch IV (Nin.) } \\
\text { Starch IV (Nin.) } \\
\text { Starch IV (Nin.) } \\
\text { Starch V (Nin.) } \\
\text { Dowex-50 (Nin.) } \\
\text { Dowex-50 (Nin.) }\end{array}$ & $\begin{array}{l}2 \\
1 \\
1 \\
1 \\
1 \\
2 \\
1 \\
1 \\
1 \\
1\end{array}$ & 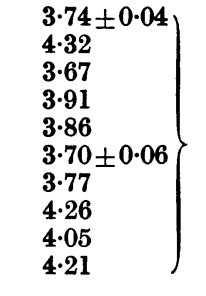 & $3 \cdot 92$ & $\mathbf{3} \cdot \mathbf{3}$ \\
\hline Methionine & $\begin{array}{l}\mathbf{D} \\
\mathbf{A} \\
\mathbf{B}\end{array}$ & $\begin{array}{l}\text { Starch I (Nin.) } \\
\text { Starch I (Nin.) } \\
\text { Starch I (Nin.) }\end{array}$ & $\begin{array}{l}\mathbf{1} \\
\mathbf{3} \\
\mathbf{2}\end{array}$ & $\begin{array}{l}0 \cdot 314 \\
0 \cdot 320 \pm 0 \cdot 008 \\
0 \cdot 318 \pm 0 \cdot 018\end{array}$ & 0.32 & 0.56 \\
\hline Phenylalanine & $\begin{array}{l}\mathbf{E} \\
\mathbf{D} \\
\mathbf{C}\end{array}$ & $\begin{array}{l}\text { Starch I (Nin.) } \\
\text { Starch I (Nin.) } \\
\text { Starch I (Nin.) }\end{array}$ & $\begin{array}{l}\mathbf{1} \\
\mathbf{3} \\
\mathbf{2}\end{array}$ & $\left.\begin{array}{l}2 \cdot 20 \\
2 \cdot 02 \pm 0 \cdot 04 \\
2 \cdot 11 \pm 0 \cdot 02\end{array}\right\}$ & $2 \cdot 07$ & $4 \cdot 0$ \\
\hline Proline & $\begin{array}{l}\mathbf{A} \\
\mathbf{B} \\
\mathbf{A} \\
\mathbf{B} \\
\mathbf{A} \\
\mathbf{B}\end{array}$ & $\begin{array}{l}\text { Starch VI (Nin.) } \\
\text { Starch VI (Nin.) } \\
\left.\text { Starch V ( }{ }^{84} \mathrm{Cu}\right) \\
\left.\text { Starch V }{ }^{84} \mathrm{Cu}\right) \\
\text { Starch V (Nin.) } \\
\text { Starch V (Nin.) }\end{array}$ & $\begin{array}{l}3 \\
1 \\
1 \\
1 \\
2 \\
2\end{array}$ & $\left.\begin{array}{l}4 \cdot 96 \pm 0 \cdot 03 \\
5 \cdot 04 \\
5 \cdot 18 \\
5 \cdot 35 \\
5 \cdot 03 \pm 0 \cdot 15 \\
4 \cdot 98 \pm 0 \cdot 15\end{array}\right\}$ & $5 \cdot 05$ & $6 \cdot 8$ \\
\hline
\end{tabular}


Table 1 (cont.)

\begin{tabular}{|c|c|c|c|c|c|c|}
\hline $\begin{array}{l}\text { Amino } \\
\text { acid }\end{array}$ & Hydrolysate & $\begin{array}{l}\text { Method of separation } \\
\text { and estimation }\end{array}$ & $\begin{array}{c}\text { No. of } \\
\text { estimations }\end{array}$ & $\begin{array}{l}\text { Amino acid } N \\
\text { (as \% total } N \text { ) }\end{array}$ & $\begin{array}{l}\text { Average } \\
\text { amino } \\
\text { acid } N \\
\text { (as \% } \\
\text { total } N \text { ) }\end{array}$ & $\begin{array}{c}\text { Amino } \\
\text { acid/100 } \mathrm{g} . \\
\text { wool }\end{array}$ \\
\hline Serine & $\begin{array}{l}\text { L } \\
\text { M } \\
\text { C } \\
\text { D } \\
\text { A } \\
\text { B } \\
\text { A } \\
\text { B }\end{array}$ & $\begin{array}{l}\text { Rees (1946) } \\
\text { Rees (1946) } \\
\left.\text { Starch IV }{ }^{64} \mathrm{Cu}\right) \\
\text { Starch IV }{ }^{\left({ }^{64} \mathrm{Cu}\right)} \\
\text { Starch IV (Nin.) } \\
\text { Starch IV (Nin.) } \\
\text { Starch V (Nin.) } \\
\text { Starch V (Nin.) }\end{array}$ & $\begin{array}{l}1 \\
5 \\
1 \\
1 \\
2 \\
1 \\
1 \\
2 \\
2\end{array}$ & $\left.\begin{array}{l}8 \cdot 41 \\
8 \cdot 00 \pm 0 \cdot 12 \\
8 \cdot 51 \\
7 \cdot 97 \\
8 \cdot 14 \pm 0 \cdot 06 \\
7 \cdot 77 \\
7 \cdot 51 \pm 0 \cdot 06 \\
7 \cdot 66 \pm 0.08\end{array}\right\}$ & $7 \cdot 87$ & $9 \cdot 7$ \\
\hline Threonine & $\begin{array}{l}\mathbf{A} \\
\mathbf{B} \\
\mathbf{L} \\
\mathbf{M}\end{array}$ & $\begin{array}{l}\text { Starch VI (Nin.) } \\
\text { Starch VI (Nin.) } \\
\text { Rees (1946) } \\
\text { Rees (1946) }\end{array}$ & $\begin{array}{l}\mathbf{3} \\
\mathbf{3} \\
\mathbf{2} \\
\mathbf{5}\end{array}$ & $\left.\begin{array}{l}4 \cdot 74 \pm 0 \cdot 16 \\
4 \cdot 69 \pm 0 \cdot 04 \\
4 \cdot 55 \pm 0 \cdot 05 \\
4 \cdot 56 \pm 0 \cdot 02\end{array}\right\}$ & $\begin{array}{l}4 \cdot 71 \\
4 \cdot 56\end{array}$ & $\begin{array}{l}6 \cdot 5 \\
6 \cdot 3\end{array}$ \\
\hline Tryptophan & See text & Starch III (Nin.) & See text & - & 0.82 & 0.94 \\
\hline Tyrosine & $\begin{array}{l}\mathbf{A} \\
\mathbf{B} \\
\mathbf{A} \\
\mathbf{B} \\
\mathbf{N} \\
\mathbf{O} \\
\mathbf{P} \\
\mathbf{Q} \\
\mathbf{R}\end{array}$ & $\begin{array}{l}\left.\text { Starch III }{ }^{(64} \mathrm{Cu}\right) \\
\left.\text { Starch III }{ }^{(64} \mathrm{Cu}\right) \\
\text { Starch III }(\mathrm{Nin}) \\
\text { Starch III (Nin.) } \\
\text { Lugg (1937) } \\
\text { Lugg (1937) } \\
\text { Thomas (1944) } \\
\text { Thomas (1944) } \\
\text { Thomas (1944) }\end{array}$ & $\begin{array}{l}1 \\
1 \\
2 \\
2 \\
2 \\
8 \\
8 \\
3 \\
2 \\
2 \\
2\end{array}$ & $\left.\begin{array}{l}2 \cdot 57 \\
2 \cdot 66 \\
2 \cdot 64 \pm 0.01 \\
2 \cdot 62 \pm 0.09 \\
2 \cdot 83 \pm 0.03 \\
2 \cdot 75 \pm 0.03 \\
2 \cdot 63 \pm 0.01 \\
2 \cdot 65 \pm 0.01 \\
2 \cdot 63 \pm 0.03\end{array}\right\}$ & $\begin{array}{l}2 \cdot 79 \\
2 \cdot 64\end{array}$ & $\begin{array}{l}5 \cdot 9 \\
5 \cdot 6\end{array}$ \\
\hline Valine & $\begin{array}{l}\mathbf{A} \\
\mathbf{B} \\
\mathbf{E} \\
\mathbf{D} \\
\mathbf{C}\end{array}$ & $\begin{array}{l}\left.\text { Starch II ( }{ }^{(64} \mathrm{Cu}\right) \\
\text { Starch II }\left({ }^{64} \mathrm{Cu}\right) \\
\text { Starch II (Nin.) } \\
\text { Starch II (Nin.) } \\
\text { Starch II (Nin.) }\end{array}$ & $\begin{array}{l}\mathbf{1} \\
\mathbf{1} \\
\mathbf{3} \\
\mathbf{3} \\
\mathbf{2}\end{array}$ & $\left.\begin{array}{l}4 \cdot 24 \\
4 \cdot 21 \\
4 \cdot 20 \pm 0 \cdot 04 \\
4 \cdot 08 \pm 0 \cdot 06 \\
4 \cdot 15 \pm 0 \cdot 02\end{array}\right\}$ & $4 \cdot 16$ & $5 \cdot 7$ \\
\hline
\end{tabular}

Table 2. Losses of amino acids during acid hydrolysis

For further details see text.

\begin{tabular}{lcc}
\multicolumn{1}{c}{ For further details see text. } & $\begin{array}{c}\text { Ammonia } \\
\text { formed } \\
\text { (N as \% }\end{array}$ \\
Amino acid & $\begin{array}{c}\text { Recovery } \\
(\%)\end{array}$ & total N) \\
Serine & $90 \cdot 8$ & $9 \cdot 1$ \\
Threonine & 91.7 & $3 \cdot 5$ \\
Phenylalanine & $97 \cdot 6$ & $0 \cdot 5$ \\
Arginine & 100 & 0.3
\end{tabular}

present. Although the chromatographic estimation of $10 \cdot 3 \mathrm{~g}$. cystine $/ 100 \mathrm{~g}$. wool cannot account for the total sulphur in wool we prefer to record it as being nearer the true figure than the Shinohara value.

The results of the present amino acid analysis of wool are given in Table 3, together with the analyses by Simmonds (1954) and by Graham et al. (1949). The figures for serine, threonine and phenylalanine shown in Table 3 have been corrected by the factors $100 / 90 \cdot 8,100 / 91 \cdot 7$ and $100 / 97 \cdot 6$, respectively, in accordance with the losses of these amino acids in recovery experiments (Table 2). Whilst the correction factors are probably too low, because there is evidence, at least for serine, that amino acid residues decompose more rapidly when combined than in the free state (e.g. Corfield \& Robson, 1953), the exact amounts of decomposition cannot be determined.
There is an excess of ammonia in wool hydrolysates over that due to amide hydrolysis, but this cannot confidently be used as a measure of the decomposition of threonine, serine and phenylalanine as there is some uncertainty in the amide ammonia estimation. It is certain, however, that the whole of the excess ammonia cannot be accounted for if the rates of decomposition of serine, threonine, phenylalanine and arginine are no greater during the hydrolysis of wool than under the conditions of the experiments in Table 2.

The agreement between our amino acid analyses and those of Simmonds (1954) is not so close as might have been expected in view of the fact that they were both obtained from samples of Australian 64's quality wool. In particular, his estimations of alanine, histidine, isoleucine, leucine, lysine, phenylalanine and valine are $20 \%$ or more lower than our figures. The nitrogen balances of the two analyses are both close to $100 \%$, but that of Simmonds includes the nitrogen from two unidentified peaks he found on his chromatograms, one of which is probably due to hydroxylysine. This amino acid has been found previously in wool hydrolysates by Van Slyke, Hiller \& McFadyen (1941) and its presence confirmed by Middlebrook (1949), but it comprises only $0.18 \%$ of the wool. No unidentified peaks were found on starch chromatograms, but it is 
Table 3. Amino acid analyses of wool by various authors

\begin{tabular}{|c|c|c|c|}
\hline Amino acid & $\begin{array}{c}\text { Simmonds } \\
(1954)\end{array}$ & $\begin{array}{c}\text { Present } \\
\text { work }\end{array}$ & $\begin{array}{c}\text { Graham, } \\
\text { Waitkoff } \\
\text { \& Hier } \\
\text { (1949) }\end{array}$ \\
\hline Alanine & $3 \cdot 51$ & $4 \cdot 12$ & 一 \\
\hline Amide $N$ & $7 \cdot 46^{*}$ & $6 \cdot 73$ & - \\
\hline Arginine & $20 \cdot 3$ & $19 \cdot 1$ & $21 \cdot 1$ \\
\hline Aspartic acid & $4 \cdot 24$ & $4 \cdot 38$ & $4 \cdot 7$ \\
\hline Cystine & $7.93(4.95)$ & $7 \cdot 30$ & $9 \cdot 9$ \\
\hline Glutamic acid & $8 \cdot 58$ & $8 \cdot 48$ & $9 \cdot 2$ \\
\hline Glycine & $5 \cdot 80$ & $6 \cdot 29$ & - \\
\hline Histidine & 1.46 & 1.91 & $1 \cdot 8$ \\
\hline Isoleucine & 1.97 & $2 \cdot 44$ & $\mathbf{3} \cdot \mathbf{0}$ \\
\hline Leucine & 4.90 & $5 \cdot 85$ & $5 \cdot 3$ \\
\hline Lysine & $3 \cdot 25$ & $3 \cdot 92$ & $3 \cdot 9$ \\
\hline Methionine & $0 \cdot 39$ & 0.32 & 0.4 \\
\hline Phenylalanine & $1 \cdot 75$ & $2 \cdot 12 \dagger$ & $2 \cdot 1$ \\
\hline Proline & $5 \cdot 33$ & $5 \cdot 05$ & $6 \cdot 1$ \\
\hline Serine & $7 \cdot 25$ & $8 \cdot 66 \dagger$ & - \\
\hline Threonine & $4 \cdot 61$ & $5 \cdot 12 \dagger$ & $4 \cdot 8$ \\
\hline Tryptophan & $1 \cdot 73$ & 0.82 & - \\
\hline Tyrosine & $2 \cdot 97$ & $2 \cdot 62$ & $2 \cdot 7$ \\
\hline Valine & $\mathbf{3 \cdot 5 7}$ & $4 \cdot 16$ & $4 \cdot 2$ \\
\hline Unknown (1) & $1 \cdot 18$ & - & - \\
\hline Unknown (2) & 0.71 & 一 & - \\
\hline Total & $98 \cdot 89$ & $99 \cdot 39$ & $79 \cdot 2$ \\
\hline
\end{tabular}

* Uncorrected for decomposition of serine and threonine during hydrolysis.

$\dagger$ Corrected for loss during hydrolysis.

possible that an unknown, present in small amount, might have coincided with a known amino acid peak and thereby escaped detection. The total $\mathrm{N}$ and total $S$ contents of the two wool samples are also different.

On the whole our analyses agree well with those of Graham et al., the agreement for five amino acids being within $\pm 5 \%$ and for ten within $\pm 10 \%$, with larger discrepancies in the estimations of proline, isoleucine, cystine and methionine. This last only occurs to the extent of $0.5-0.7 \%$ in wool and is consequently difficult to determine accurately, and the large discrepancies between cystine estimations obtained by different methods have already been mentioned.

As Simmonds has pointed out, wool is almost certainly not a homogeneous protein, and differences in the amino acid composition of different wool samples are to be expected. This contention is supported by the analytical data shown in Table 3.

\section{SUMMARY}

1. The amino acid composition of a sample of Australian Merino 64's quality wool has been determined.

2. The results obtained have been compared with recent amino acid analyses of wool.

We are indebted to Miss B. Skinner for considerable assistance with the experimental work, and to Dr F. 0 . Howitt for his helpful advice during the course of this work. We thank the Director and Council of the Wool Industries Research Association for permission to publish this paper.

\section{REFERENCES}

Alexander, B., Landwehr, G. \& Seligman, A. M. (1945). J. biol. Chem. 160, 51.

Bailey, K. (1937). Biochem. J. 31, 1396.

Barritt, J. (1934a). J. Soc. chem. Ind., Lond., 53, 291 T.

Barritt, J. (1934b). Biochem. J. $28,1$.

Blackburn, S. \& Robson, A. (1953). Biochem. J. 54, 295.

Brand, E. \& Kassell, B. (1939). J. biol. Chem. 131, 486.

Chibnall, A. C., Rees, M. W. \& Williams, E. F. (1943). Biochem. J. 37, 354.

Corfield, M. C. \& Robson, A. (1953). Biochem. J. 55, 517.

Cuthbertson, W. R. \& Phillips, H. (1945). Biochem. J. $39,7$.

Graham, C. E., Waitkoff, H. K. \& Hier, S. W. (1949). J. biol. Chem. 177, 529.

Lugg, J. W. H. (1937). Biochem. J. 31, 1422.

Markham, R. (1942). Biochem. J. 36, 790.

Middlebrook, W. R. (1949). Nature, Lond., 164, 321.

Moore, S. \& Stein, W. H. (1948). J. biol. Chem. 176, 367.

Moore, S. \& Stein, W. H. (1949). J. biol. Chem. 178, 53.

Moore, S. \& Stein, W. H. (1951). J. biol. Chem. 192, 663.

Phillips, D. M. P. (1954). Nature, Lond., 173, 1092.

Rees, M. W. (1946). Biochem. J. 40, 632.

Rimington, C. (1929). Biochem. J. 23, 41.

Shinohara, K. (1935). J. biol. Chem. 109, 665.

Simmonds, D. H. (1954). Aust. J. biol. Sci. 7, 96.

Spies, J. R. \& Chambers, D. C. (1948). Analyt. Chem. 20, 31.

Spies, J. R. \& Chambers, D. C. (1949). Analyt. Chem. 21, 1249.

Stein, W. H. \& Moore, S. (1948). J. biol. Chem. 176, 337.

Stein, W. H. \& Moore, S. (1949). J. biol. Chem. 178, 79.

Sullivan, M. X. \& Hess, W.C. (1944). J. biol. Chem. 155, 441.

Thomas, L. E. (1944). Arch. Biochem. 5, 175.

Van Slyke, D. D., Hiller, A. \& McFadyen, D. A. (1941). J. biol. Chem. 141, 681.

Vickery, H. B. (1940). J. biol. Chem. 132, 325. 